\title{
Higher School Teacher`s Competences: Methodology and Diagnostics
}

\section{Khoruzha}

\author{
Department of Theory and History of Pedagogy, Pedagogical Institute of Borys Grinchenko Kyiv University
}

Paper received 19.01.18; Revised 24.01.18; Accepted for publication 25.01.18.

https://doi.org/10.31174/SEND-PP2018-154VI64-06

\begin{abstract}
The article dwells on methodological foundations of higher school lecturer`s researching competences as well as developing diagnostic tools to define tendencies taking place in professional activity of a lecturer in modern conditions. The article also signifies lecturer`s main competence spheres (academic, professional and pedagogical, social and personality). Materials presented in the paper will enable the diagnostic process of modern lecturer's competence development assessment in Ukraine, Poland, Czech Republic and Slovakia within the framework of realization of international scientific project. The questionnaire for students and university lecturers is also presented.

Keywords: competence, methodology, diagnostics, higher school lecturer, measurements, lecturer`s professional activity spheres.
\end{abstract}

Relevance of the Topic. The fast processes of development of European countries happening on the global, as well as regional and local levels, social, economic, technologic processes, constant transformations in the sphere of higher education provoke a number of contradictory phenomena and processes. From one hand, there are increasing demands to higher school lecturer's activity, from the other hand - instability, lecturer's uncertainty in future; being not ready to information «tsunami», critical perception of information, integral approach to analyzing phenomena and processes.

In this context, a great importance has in time diagnostics of higher school lecturer's perception level of changes, happening in his professional area, as well as finding out appropriate transformations, predicting positive and negative tendencies. The project "Higher School Lecturer's Competences in the Epoch of Changes" funded by Vyshehrad Fund aims to solve the abovementioned problems. Scholars of four countries (Ukraine, Poland, Czech Republic and Slovakia) participate in the research.

Analyzing changes, we should mention that world becomes more globalized in last centuries. Globalization made possible its openness as a smart-system (connectable landscape) in its different aspects, first and foremost in education. A number of educated people grow, as well as an amount of time spent on education; new life values form in those who educate: adaptability, flexibility, life sustainability, understanding key challenges of the time; active implementation of new technologies in the sphere and others. The European Commission paper on «Modernization of Higher Education in Europe: Academic Staff 2017» [5] dwells on variable processes taking place in systems of higher education in European countries. A great importance is given on widening of higher education informational space by implementing ICT, resource provision; modernization and search for common approaches to its quality increase, making the problem of integration of educational systems of different countries topical; changing regulatory provision and mechanisms of higher education management; demographic situation etc. In the context of these problems, social importance of higher school lecturer's activity grows, doing significant creative, intellectual, spiritual mission of future specialist preparation for sustainable society development. Future highly-qualified, competitive specialist preparation depends on the quality of teaching of educational courses at higher educational establishment. However, in the EU countries there is no centralized system of assessment of versatile higher school lecturer`s activities. Thus, there is necessity to standardize marks a lecturer as the main subject of the educational process, as well as to develop appropriate standardized approaches, helping to integrate educational systems of different countries.

Education quality indicator, introduced by structural reform of higher education on the European level (The Bolo- gna Process), is a competence. This complex system formation, comprising professional knowledge, skills, methods and techniques of professional activity, a number of settings and orientations, acquired experience allowing a lecturer to achieve high educational results. Thus, quality increase of higher education is directly connected to staff development, namely competences of university teaching staff. This problem is one of the most important social and economictasks. Its solution will resultinto increase of manpower in every country.

The Analysis of the Research. The problem of defining of the nature of pedagogue's and higher school lecturer`s competences is a subject scientific research of many scholars. Analyzing this problem, researchers state that, many professional functions, performed by a lecturer, enable consideration of his activity as a non-linear system, capable of self-organization and development on the basis of awareness of his own image and professional identity [6].

To define the content of higher school lecturer's competences, we analyzed results of the project DeSeCo, carried out by researchers in the context of OECD. Researchers summarized results and conclusions of 3 projects: the CrossCurricular Competencies Project, International Adult Literacy Survey (IALS) and the Human Capital Project. Partially materials of the International Project on the Adult Literacy and Lifeskills (ALL), as well as the International Association for the Evaluation of Educational Achievement (IEA) [1] were studied. The content of education was re-interpreted and presented as a scope of competences. The main groups of competences is defined as an ability to use instruments of communication with the environment (language, knowledge, ICT etc.); interact with people in diverse groups; act independently (autonomous).

It is worth mentioning there are different approaches to defining and classifying competences in Pedagogy. Famous elaboration of pedagogue`s competences, made by Ukrainian and foreign scholars: I.Zymnya, P. Light, V.Luhovyi, D.Miller, K.Rogers, O.Pometun, O.Savchenko, A.Khutorsky, M. Tsvenher and others). In elaboration of these scholars there is nocommon approach to classifying competences.

The Purpose Formulation of the Article. The aim of the paper is to define methodological foundations of developing diagnostic tools to study competences of a modern higher school lecturer in four European countries: Ukraine, Poland, Czech Republic and Slovakia, enabling identification of development tendencies of these competences in the context of global and local changes in educational sphere.

The Main Material. Complexity of measuring competences consists in the fact that lecturer`s activity is a multiaspect process. The lecturer performs research, educational, project, organizational, evaluating, innovative and other functions. Some scholars study the content of discrete competences according to abovementioned functions. We find 
this approach not productive and quite difficult for quantitative analysis. Therefore, the foundation of development of diagnostic tools to identify modern changes in higher school lecturer's competences was made by materials of Project TUNING [7], as far as formation of new ideas is characterized not only by exceeding the limits of something perceived before, but also by becoming a part of already formed system of knowledge [4, p.37].

So, according to the Project TUNING, scholars`opinions on the structure of general competences (instrumental, interpersonal and system) university student have to possess were set as foundation. This statement gave certain guidelines to conclude the following: «anything, a student needs, a lecturer must have». That is why, defined competence categories in the structure of a general competence were takes as basics and studied in three professional dimensions of higher school lecturer's activity: academic, professional and pedagogical, and social and personality. The choice of these lecturer's competence spheres meets the following general criteria: universality as an important requirement to all lecturers, performing educational activity; eligibility to the development of educational process of higher educational establishment; significance to all lecturers of different universities in European countries. Identical views we can also find in works of Ukrainian scholar S.Masych, who has grouped professional competences according to the main professional activity categories [3]. So, mentioned methodological approach allowed to take into consideration the content of general and partially subject competences, referred in the Project TUNING, as well as summarize different activities and functions of a lecturer defining his competences.

Spheres of higher school lecturer's professional activity (academic, professional and pedagogical, and social and personality reflect its diversity and present certain competence plurality, allowing to study competences as a managed and self-manages system.

Using Venn diagram we can further outline all possible interconnections of these subsets [8].

Basing on these methodological backgrounds, the following tasks of diagnostics are formulated:

1. Develop special tools for impartial assessment of lecturer's competence development at universities of four countries: Ukraine, Poland, Czech Republic and Slovakia.
2. Identify contemporary content of higher school lecturer's competences, level of diversity and changes in four European countries: Ukraine, Poland, Czech Republic and Slovakia.

3. Define development tendencies of lecturer's competences and their dominance in professional activity and in students` marks.

4. Elicited results allow to start a joint international discussion of higher school lecturer's competences at the European level between the project participants, at the level of non-governmental public organizations, engaged in problems of higher education, and also at state level of branch Ministries and departments.

5. Carried research can become a background for organization of an advanced training system of higher school lecturers in participant countries, because competences are not constant and develop through experience, studies and self-development.

The basis for the diagnostic development is a phenomenon of a mark as an ability of a person to determine the value of ideas or statements. Not only lecturers but also students were chosen as respondents of a diagnostic, because student expectations towards lecturer's activity is an important quality education indicator allowing determination of corresponding correlation connections between diagnostic measurement results in two groups.

Basic characteristics of developed diagnostics are the following:

- inclusion of subjects in the pedagogical system, process;

- presence of aims of pedagogical assessment;

- using appropriate techniques;

- simplicity of accomplishment;

- obtaining of real, efficient information;

- predictable character to evaluate the real condition and identify appropriate tendencies.

The principle approach to constructing the questionnaire for lecturers and students was the same content in terms of statement-characteristics, the personal dominance of which has to be assessed by respondents. For this purpose, a fourdimensional assessment scale has been developed: Yes (I fully agree); more Yes than No; more No than Yes; No (I completely disagree).

Below you can find a list of statements, underlying the questionnaire.

\begin{tabular}{|c|c|c|c|c|c|}
\hline \multirow{15}{*}{ 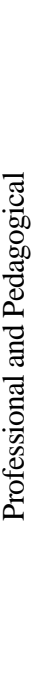 } & Lecturer: & Yes & $\begin{array}{l}\text { more Yes } \\
\text { than No; }\end{array}$ & $\begin{array}{l}\text { more No } \\
\text { than Yes; }\end{array}$ & No \\
\hline & Constantly improves himself / herself, improves his / her intellectual and professional level & & & & \\
\hline & Introduces innovative learning technologies, including ICT & & & & \\
\hline & Works with information in global networks based on its critical analysis & & & & \\
\hline & Uses various means of communication with students and colleagues, including ICT & & & & \\
\hline & $\begin{array}{l}\text { Uses fundamental knowledge in the educational process, the achievements of modern science, } \\
\text { constantly updates the content of educational courses }\end{array}$ & & & & \\
\hline & $\begin{array}{l}\text { Creates an educational environment, that contributes to cognitive activity of students, research } \\
\text { based learning }\end{array}$ & & & & \\
\hline & Creates distance learning courses & & & & \\
\hline & Is able to use the technology of managing of students` self-study & & & & \\
\hline & Shows flexibility in professional activity, enterprising initiative & & & & \\
\hline & $\begin{array}{l}\text { Considers interactive coordination with students the most productive in the educational process, } \\
\text { organizes group and collective project activities }\end{array}$ & & & & \\
\hline & Is able to set and achieve the didactic goal according to SMART technology with students & & & & \\
\hline & Uses different technologies of monitoring educational outcomes, corrects them & & & & \\
\hline & Has a positive attitude to reforms and changes that take place in higher education & & & & \\
\hline & Is satisfied with the results of his professional activity & & & & \\
\hline
\end{tabular}

So, competences mentioned in the questionnaire are grouped by lecturer's main activity types and have integral character. Further analysis of diagnostics results makes pos- sible to identify common and different tendencies of higher school lecturer's competences development in the epoch of changes in four European countries. 
2.

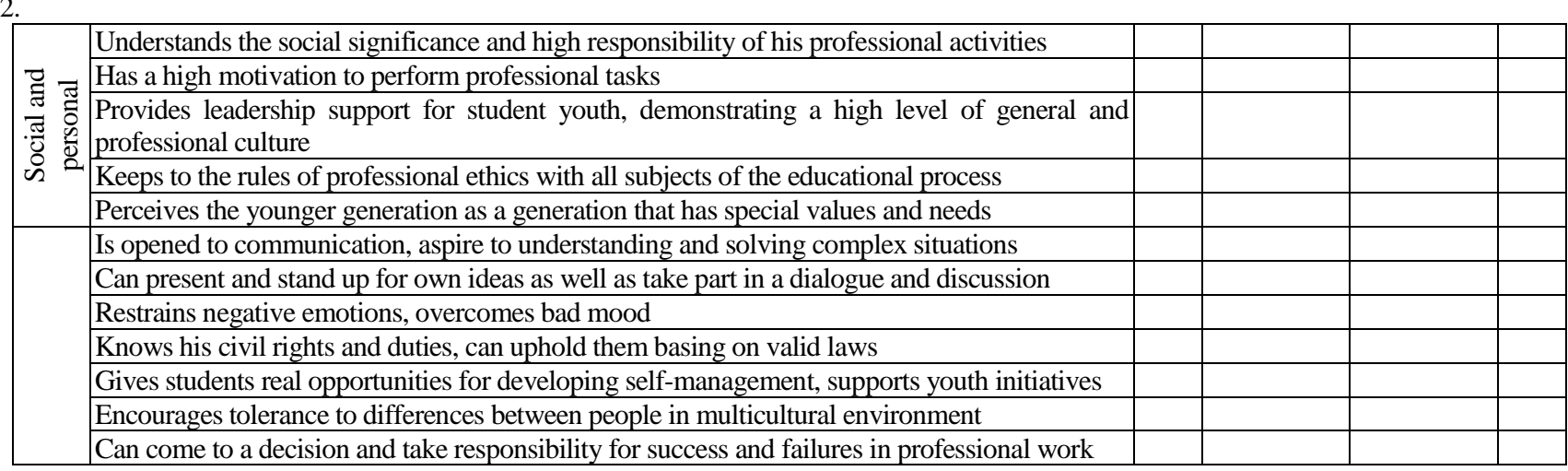

3.

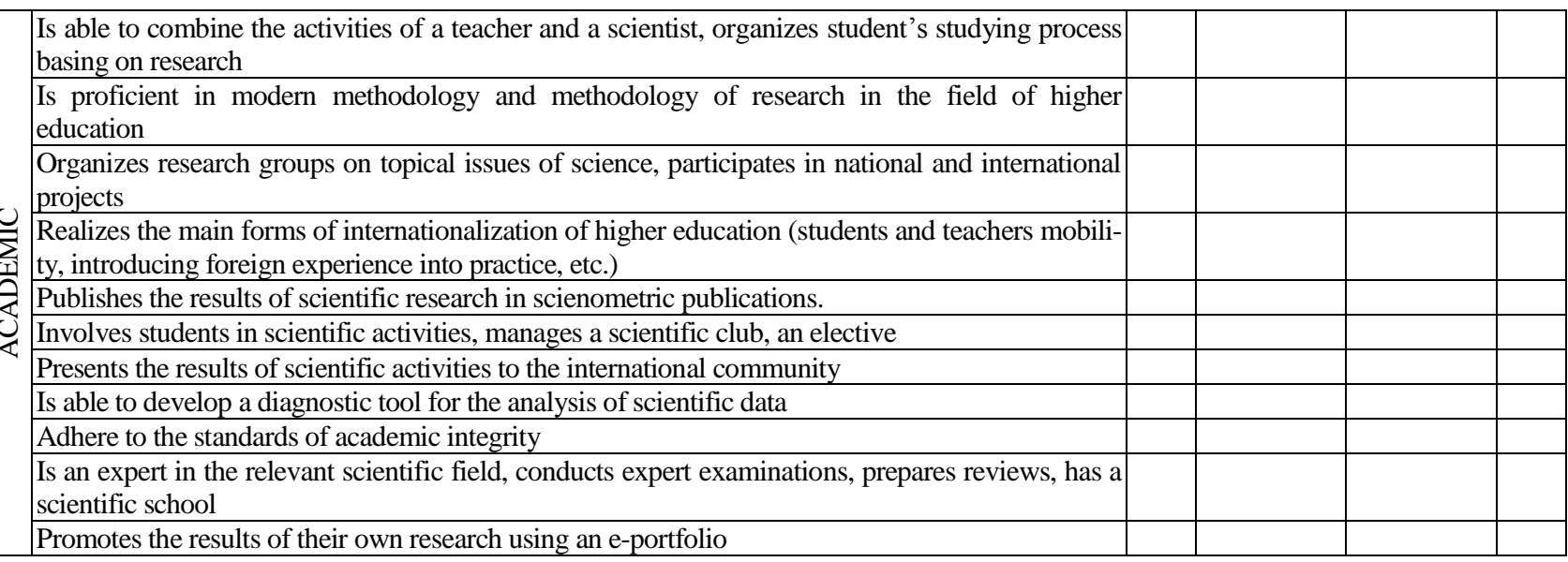

Conclusions. Analysis of European documents on education and scholars` research on pedagogue`s and higher school lecturer's competences allowed to identify certain methodological ideas and logical lines, that became a foundation to develop an appropriate diagnostic tool. New level of understanding methodological approaches to the problem, made possible to analyze higher school lecturer's competences in three professional dimensions of his work: academic, professional and pedagogical, social and personal. Tasks and basic characteristics of the diagnostics are determined; four-dimension scale of competence assessment is developed

\section{REFERENCES (TRANSLATED AND TRANSLITERATED)}

1. Development of key competences in education: some lessons from international experience. / URL :http://www.ibe.unesco.org/cops/russian/IBE_Competences.pdf).

2. Luhovyy V.I.,Slyusarenko O.M.,Talanova Zh.V. Identification of the composition and structure of competencies is a key condition for increasing the effectiveness of teaching and evaluating learning outcomes in higher education. / [V.I. Luhovyy,O.M.Slyusarenko,Zh.V.Talanova] // Vyshcha shkola Ukrayiny. - № 3(dodadok). - Tematychnyy vypusk. Pedahohika vyshchoyi shkoly: metodolohiya, teoriya, tekhnolohiyi. - T. 1. Kyiv,2011. - S.9-16. -636 s.

3. Masych S.Yu. The system of competences of a teacher of a higher educational institution. / S. Yu. Masych // Pedahohika ta psykholohiya. - 2014. - Vyp. 45. - S. 135-143. in the article. Arguments and developing of diagnostic tools to assess higher school lecturer`s competences allows to identify appropriate transformations, predict positive and negative tendencies, taking place within the scope of lecturer`s competences nowadays. Our generalizations and conclusions are a background data for realization of international project "Higher School Lecturer's Competences in the Epoch of Changes" funded by Vyshehrad Fund and participating scholars from Ukraine, Poland, Czech Republic and Slovakia.

4. Methodology of pedagogy: monograph. / E.A. Aleksandrova, R.M. Asadullyn, E.V.Berezhnova [y dr.] ; pod obshch.red. V.H.Ryndak. - M.: YNFRF - M, 2018. - 296 s.

5. Modernisation of Higher Education in Europe: Academic Staff 2017. - European Commission/EACEA/Eurydice, 2017. Eurydice Report, Luxembourg: Publication Office of the European Union.

6. Shelton A. Introduction to professional pedagogy. /A.Shelton: uchebnoe posobye. -Ekaterynburh,UHPPU, 1996. - $288 \mathrm{~s}$.

7. Tuning Education Structures in Europe [Electronic resource]. URL:http://tuning.unideusto.org

8. Venn diagram / [Elektronnyy resurs]. URL:http://ru.m.wikipedia.org.].

\section{Компетенции преподавателя высшей школи: методология и диагностика}

\section{Л. Л. Хоружая}

Аннотация. В статье рассматриваются методологические основы изучения компетенций преподавателя высшей школы, а также создания диагностического инструментария их изучения с целью определения тенденций, которые происходят в профессиональной деятельности преподавателя в современных условиях. Выделены его основные компетентностные сферы: академическая, профессионально-педагогическая, социально-личностная. Представленные в статье материалы позволят провести диагностические процедуры оценки развития компетенций современных преподавателей в Украине, Польше, Чехии иа Словакии в рамках реализации международного научного проекта. Представлен также опросник для студентов и преподавателей университетаю

Ключевые слова: компетенция, методология, диагностика, преподаватель высшей иколы, измерения, сферы профессиональной деяльности преподавателя. 